\title{
The Effect of Adverse Selection and Psychological Capital on Decision Making Involving Escalation Situations: An Experimental Study
}

\author{
I Made Narsa \& Niluh Putu Dian Rosalina Handayani Narsa* \\ Universitas Airlangga, Jl. Airlangga no 4-6, Surabaya, Jawa Timur, Indonesia \\ *(niluh.narsa@feb.unair.ac.id)
}

\section{Riwayat Artikel: \\ Tanggal diajukan: \\ 4 Desember 2020 \\ Tanggal diterima: \\ 30 Maret 2021}

Tanggal dipublikasi daring:

25 Juni 2021

Keywords: adverse selection; agency theory; escalation of commitment; psychological capital

\section{Pengutipan:}

Narsa, I Made \& Narsa, Niluh Putu Dian Rosalina Handayani. (2021). The Effect of Adverse Selection and Psychological Capital on Decision Making Involving Escalation Situation: An Experimental Study. JIA (Jurnal Ilmiah Akuntansi), Vol. 6, No.1, Hal: 01-21.

Kata Kunci: adverse selection; eskalasi komitmen; psychological capital; teori keagenan

\begin{abstract}
This study examines the determinant of structural variable (adverse selection) and psychological variable (psychological capital - PsyCap) on manager's tendency to escalate their commitment. This study used $2 \times 2$ factorial experimental design as a research method. The participant of this study is management and accounting master students who act as the surrogate of project manager. Used ANOVA as the data analysis technique, this study found a main effect of adverse selection and PsyCap in predict the escalation of commitment. However, there is no effect of the interaction between those two variables on escalation of commitment. This study contributes to the literature of escalation of commitment as well as psychological capital literature, considering that PsyCap is always associated with positive outcome but this study found that the high PsyCap might also predict undesirable outcome such as escalation of commitment.
\end{abstract}

ABSTRAK
Penelitian ini mengkaji determinan variabel struktural
(adverse selection) dan variabel psikologis (psychological
capital - PsyCap) pada kecenderungan manajer untuk
meningkatkan komitmennya. Penelitian ini
menggunakan rancangan eksperimen faktorial $2 \times 2$.
Partisipan dalam penelitian ini adalah mahasiswa
magister manajemen dan akuntansi yang bertindak
sebagai penyulih manajer proyek. Menggunakan ANOVA
sebagai teknik analisis data, penelitian ini menemukan
efek utama dari adverse selection dan PsyCap dalam
memprediksi eskalasi komitmen. Namun, tidak ada
pengaruh interaksi antara kedua variabel tersebut
terhadap eskalasi komitmen. Studi ini berkontribusi
pada literatur eskalasi komitmen serta literatur modal
psikologis, mengingat PsyCap selalu dikaitkan dengan
hasil positif tetapi penelitian ini menemukan bahwa
PsyCap yang tinggi mungkin juga dapat memprediksi
hasil yang tidak diinginkan seperti eskalasi komitmen.

\section{ABSTRAK}

Penelitian ini mengkaji determinan variabel struktural (adverse selection) dan variabel psikologis (psychological capital - PsyCap) pada kecenderungan manajer untuk menggunakan rancangan eksperimen faktorial $2 \times 2$. Partisipan dalam penelitian ini adalah mahasiswa magister manajemen dan akuntansi yang bertindak sebagai penyulih manajer proyek. Menggunakan ANOVA sebagai teknik analisis data, penelitian ini menemukan efek utama dari adverse selection dan PsyCap dalam memprediksi eskalasi komitmen. Namun, tidak ada pengaruh interaksi antara kedua variabel tersebut terhadap eskalasi komitmen. Studi ini berkontribusi pada literatur eskalasi komitmen serta literatur modal hasil positif tetapi penelitian ini menemukan bahwa PsyCap yang tinggi mungkin juga dapat memprediksi hasil yang tidak diinginkan seperti eskalasi komitmen. 


\section{INTRODUCTION}

Escalation of commitment is simply a decision error which happens when a person (specifically a project manager) tend to continue an unprofitable project (Bowen, 1987). Escalation of commitment can occur in various situations even in everyday life, such as waiting for scheduled bus, keeping the losing shares, retaining employees who are not performing well, or even putting all effort into a conflict such as the Vietnam War (Moser, Wolff, and Kraft, 2013) anf of course in practical business. The existence of this decision bias in practical business world make it not suprising if this phenomenon has been noted as an important and prominent phenomenon over the various failures of controversial organizational decisions (Sleesman, Conlon, McNamara, and Miles, 2012).

Long Island Lighting Company is one of the examples where escalation of commitment occurs in Shoreham Nuclear Power Plant project. That 'continuing project decision' resulted in the bankruptcy of the Company and make that company never operate again after continuously suffered a loss for several years (Ross and Staw, 1993). Using data collected over a period of four years, a recent longitudinal case study by Stray et al.,
(2021) also found that daily meetings of building software project in Norway contributed to maintain an escalation of commitment situation. In Indonesia, this bias also occurs, one of the most widely known examples is the Hambalang Project which until now still stuck and remain uncertain whether will be continue or will be dismissed.

From empirical point of view many researches had successfully explaining this bias. According to Street and Street (2006), research on the escalation of commitment has been overly dominated by the affective theory approach (self-justification theory). Based on this theory, escalation of commitment is very likely to occur when a project manager afraid to losing its selfesteem if not continuing a project which is initiated by him/her.

One of the other theoretical frameworks that can be used to explain the escalation phenomenon of commitment is agency theory (Ang and Cheng, 2016; Narsa and Supriyadi, 2019). Kanodia et al (1989) first suggest that other alternative explanation of escalation of commitments are required, because often the research findings have not shown consistent results and neglected the emerging agency relationships in the context of 
organizational decision making (Harrell and Harrison, 1994). Brockner (1992) also argues that, although the theory of selfjustification plays a significant role in the escalation of commitment, it can not explain the whole of escalation phenomenon. Since then many researchers have found empirical evidence that the conditions of agency problems cause individuals to escalate commitments (Ang and Cheng, 2016; Narsa \& Supriyadi, 2019).

In a meta-analysis of the determinant of escalation of commitment, Sleesman et al. (2012) states that the determinant of agency problem is a structural determinant group. Structural determinants are the least likely determinants to be studied compared to other determinant groups and are also highly dependent determinants of organizational circumstances that can sharpen commitments on projects that have failed, hence this study will test the escalation of commitments under conditions of adverse selection.

Still related to the determinants of escalation of commitment, this study will also explore the influence of individual variables named psychological capital that are statelike in nature which is quite stable but also can be malleable, differ with a trait variable like the emotion of happy and sad. Although Brande et al. 2016, Bowen et al. (2014), as well as Sleesman et al (2012) sugested that even though the individual variables is a much-explored determinant, there is still an opportunity to test individual variables especially those that rarely tested in the context of escalation commitments. Considering also that individual variable will always be noted as the most powerful discriminator in sorting those who has escalated commitments and who is not, this study will test Psychological Capital (hereafter will be called PsyCap) as the determinant of escalation of commitment (Korzaan dan Morris, 2009; Chong dan Syarifuddin, 2009). PsyCap is a multidimensional construct which is consist of self-efficacy, hope, optimis, and resilience (Luthans et al., 2007; Cavus and Gokcen, 2015).

Whereas this construct is still emerging, empirical evidence has shown that PsyCap has a positive impact on employee attitudes and behavior in the workplace such as job performance, job satisfaction, organizational commitment, psychological well-being, and other (Avey, Reichard, Luthans, and Mhatre, 2011). Many researchers always associate PsyCap with positive outcome in workplace. Leon-Perez et al. (2016) as well as Narsa and 
Wijayanti (2021) noted that PsyCap can lower the stress level in workplace thus it will improve the work performance and engagement. They found that PsyCap is negatively associated with burnout and positively associated with quality of services.

Nevertheless, it is also can not be denied that a person with high PsyCap is capable also in producing a bias that result in negative impact, as have been found by previous researchers, such as dysfunctional and unprofitable organizational output (Bird, 2005; Xu et al, 2015), risk-taking behavior (Xing and Sun, 2013), as well as Narsa and Narsa (2018) which firstly found that the overall PsyCap is related with escalation of commitment. However, the study from Narsa and Narsa (2018) has not answered th effect of the Psycap in the agency theory frame. Thus, it will be interesting to see how the influence of PsyCap on the decision making process involving the escalation situation which is considered as a behavior that can have a negative impact.

This study give the novel insights that an individual variable - PsyCap could also generate a negative impact on workplace. Along witnh the structural or situational variable adverse selection - this study comprehend its novelty by also testing its interaction to escalation of commitment. It is in accordance with the opinion that in order to understanding the behavior of an individual in organizational environment, it is important to consider both the influence of individual factor - PsyCap - and situational factor - adverse selection condition (Saks and Ashforth, 2000).

Hypothesis testing was conducted based on experimental data with 2 × 2 factorial design among subjects involving 68 masters of management and accounting students who acted as investment manager. This study successfully provides empirical evidence that individuals who faced adverse selection condition tend to escalate their decisions, individuals who have high PsyCap also tend to escalate their decision. However, there is no interaction effect between adverse selection and PsyCap to escalation of commitment.

In a sequence, the next section of this study will describe the literature review and hypothesis development. Then continued with research methods. After that will be presented about the results and discussion. Lastly, conclusion along with future research will close this article. 


\section{LITERATURE REVIEW AND HYPOTHESIS DEVELOPMENT \\ The Effect of Adverse Selection on Escalation of Commitment}

The agency problem arises because of the difference of desire or purpose between the principal and the agent, also, the principal can not verify what the agent actually does (Jensen and Meckling, 1976). In the context of the escalation of commitment, agency theory modeled the relationship between the principal i.e., the senior management of the company with the agent i.e., the project manager in a contract to complete a particular project (Booth and Schulz, 2004).

The agency theory provides a more rational explanation than psychological-based explanation. Many studies have found empirical evidence that the condition of agency problems (i.e., adverse selection) causes individuals to commit escalation of commitments (Ang and Cheng, 2014, Berg et al., 2009; Booth and Schulz, 2004; Dewi and Supriyadi, 2012; Harison and Harrell, 1993; Harrell and Harrison, 1994; Roberts, 2013; Rutledge and Karim, 1999; Salter and Sharp, 2001).

It is assumed that individuals will be motivated to take decisions that maximize their personal economic interests than to maximize the economic interests for the company. Two concepts needed to induce that to occur are information asymmetry and incentive to shirk. Information asymmetry occurs when managers who manage a project have more information than the principal so that information about the project is not openly exposed to many, only the manager knows (Narsa \& Supriyadi, 2019). Furthermore, incentive to shirk conditions occur when the reward to be received by the manager to continue the project is greater than the rewards that will be accepted if the project stopped (Salter and Sharp, 2001).

The agency theory puts managers who have both incentives to shirk and information asymmetry condition - which is called adverse selection condition -, will reach decisions that reflect the manager's personal interests that may be contrary to the objectives of his company. Precisely under these circumstances, it may be rational from the manager's point of view to continue the failed project (Harrel and Harrison, 1994; Booth and Schulz, 2004). Thus, our first hypothesis:

$\mathrm{H}_{1}$ : The project manager who facing adverse selection condition will tend to continue unprofitable project than the project manager 
who do not facing adverse selection condition.

\section{The Effect of Psychological Capital on Escalation of Commitment}

PsyCap is a multidimensional construct which is consist of selfefficacy, hope, optimis, and resilience. Firstly, self-efficacy can be defined as a person's belief in his ability to accomplish tasks (Venkatesh and Blaskovich, 2012). Bandura (1997) state that individuals with high selfefficacy have greater persistence over things because they are so confident that persistence can lead them to a successful task. However, individuals with high self-efficacy also tend to exaggerating his belief that they were able to successfully complete a particular task, which in turn would create a problem, including an irrational commitment to unsuccessful project (Csikszentmihalyi, 1997).

Some previous research findings also showed similar results. Using experimental method, by manipulate the level of self-efficacy, Whyte et al., (2007) found that participant in high self-efficacy group - which are told that they have a good track record and often succeed in some projects is the most likely to experience an escalation of commitment. Using longitudinal study, Kisfalvi (2000) found that a managers with high selfefficacy tend to be more persistent and constantly can manage themselves to keep success in certain task because they never concerned with negative things. Another researcher, although not explicitly testing the escalation of commitment Bragger, Bragger, Hantula, Kirnan, and Kutcher (2003) found that individuals who have been successful in a previous decision tend to invest more in a failing activity. Recent researchs which also test the selfefficacy on escalation of commitment is Yao et al. (2010), Babatunde (2016), Ronay et al. (2017), Narsa \& Narsa (2018). They found that self-efficacy can predict the escalation of commitment.

The second component is hope. Hope is an affective respond on a future events. Dang et al (2014) found that individuals who have higher hope - which also have no fear - tend to not concerned with a negative outcome. Snyder (2000) found that individuals who have high hope will develop a definite plan and strategy, including many alternatives plan, to achieve their goal.

The third component is optimism. Individuals who have a sense of optimism believe that the future will generate a positive 
outcome, while hope only encompasses the desires that are limited by the boundaries of reality. Luthans (2002a) argues that optimistic individuals believe that failures and obstacles are only for a shortly time and they sure that they can survice in difficult situations or problems. It is predicted that highly optimistic individuals tend to believe that they able to cope difficult and challenging situations and tend to seek more positive evidence, thus ignoring any evidence that contrary with their earlier believes (Mahlendorf and Wallenburg, 2013; Taylor and Stanton, 2007). Optimistic individualsm when facing a fact that their goal may not be achieved, will continue to strive, work hard, and never give up (Kluemper et al., 2009). However, unreasonable optimism can lead to bad choices and unrealistic actions. Babatunde (2016) and Juliusson (2006) found that an optimistic decision-makers are more willing to continue their commitment in a project because of their desire to recover sunk cost already spent.

Lastly, the fourth component is resilience. Although resilience is an evolving concept in organizational behavior literature, but psyhologists belive that resilience is relevant and related to workplace actions (Youssef and Luthans, 2007). Luthans (2002b, p. 702) defined resilience as "the developable capacity to rebound or bounce back from adversity, conflict, and failure for not only reactive recovery but also proactive learning and growth through conquering challenges". Whyte et al (1997) once stated that there might be a possible correlation between resilience and escalation of commitment. They argue that individual's belief and quicbaness to be able to bounce back from difficulties experience will encourage them to continue unprofitable or failed projects. Decision to continue failed projects could be regarded as risk-taking behavior (Bazerman et al., 1984). As found by Xing, Sun, and Resources (2013), resilience could lead individuals quickly became energetic and forget any negative situations they experienced in order to achieve good performance.

Based on comprehensive explanation above regarding the prediction of each of the components PsyCap on escalation of commitment, certainly there will be an effect of PsyCap as the single unity construct on escalation of commitment. Considering self-efficacy, hope, optimism, and resilience as an important aspect of PsyCap, it is expected that the combined effect of these variables will be more impactful than if viewed as individual variables 
(Avey et al., 2011). Moreover, before Psycap construct was formed, Bandura (1997) and Snyder (2000) once stated that people with high in self-efficacy are more resilient, a high hope also make people tend to be more convict in any specific task, and easily bounce back from temporary difficulties.

$\mathrm{H}_{2}$ : The project manager who has higher PsyCap will tend to continue unprofitable project than the project manager who has lower PsyCap.

\section{The Interaction of Adverse Selection and Psychological Capital on Escalation of Commitment}

In the escalation paradigm, the decision to escalate can be seen as risk-seeking or risk-taking behavior. This is due to increased commitment to a failed project involving harmful things, for example a great financial loss, especially for the company. With the adverse selection conditions that encourage individuals to escalate, then, thus risk-taking behavior is also colored by motivation over the opportunities to obtain rewards (Leigh, 1999).

The desire to avoid potential losses to oneself will associated with risk-taking behavior which precisely give a motivation for individuals to earn any possible rewards by continuing a failed project. The potential for such losses is a damaged reputation if fails to handle the project and also missed of opportunity to obtain greater rewards.

Chong and Syarifuddin (2010) argue that a difficult work with high uncertainty is more challenging and therefore would be appropriate or suitable for individuals with high selfesteem. This is because they have a greater ability to seek additional relevant information about their own knowledge and abilities. In turn, a work that has more routine characteristics would be suitable for individuals with low self-esteem. In conclusion, the same logic can also be used for self-efficacy, hope, optimism, and resilience especially when relate it to escalation of commitment. This is because engage in a sequence project which later show a great loss is a work with high uncertainty and very challenging.

Saks and Ashforth (2000, p. 43) states that one of the key findings regarding the understanding of workplace behavior is that individuals react differently to a similar situation. In order to be able to understand and predict behavior in organizational situation it is important to not only consider the psychological factors of the individual but also the interaction between individual variables with 
structural variables that exist in the work environment, which is in this study is adverse selection condition. It is predicted that individuals with high PsyCap are increasingly motivating in completing tasks and ignoring any obstacles - in this case is the negative information of the project regarding the losses - especially when experiencing adverse selection conditions. Thus, it is predicted that there will be interaction effect between adverse selection condition with PsyCap, that together they will predict the escalation of commitment.

$\mathrm{H}_{3}$ : When adverse selection condition is present, the project manager who has higher PsyCap tend to continue unprofitable project than the project manager who has lower PsyCap.

\section{METHOD}

\section{Experimental Design}

This study using experimental method with factorial design $2 \times 2$ between subject as presented in Table 1 below. The first factor is adverse selection condition (present and not present) and the second factor is PsyCap (high and low). Considering PsyCap is a state-like variable, rather than manipulate it, this study prefers to capture it using questionnaire. As Luthans et al (2007) argued that eventough this variable is malleable and openly to be developed, but Psycap also considered as fairly stable variable.

\section{Experimental Participant}

This research using laboratorium experiment with a master of management and accounting student who have taken management accounting courses and / or financial management as a surrogate for project manager. The reason why they selected because their characteristics are closer enough to a project manager, with additional broader knowledge than undergraduate business students (Madein and Sholihin (2015); Rutledge dan Karim, 1999). Such requirements are important, considering the case of escalation of commitment in business context always about capital budgeting. Thus, their selection as project manajer is fairly appropriate (Buxton and Rivers, 2014). Of the 60 participants whose data was further processed (can be seen in Table 2), 38 of them were master of accounting students and the remaining 22 were master of management students.

The total participant in each cell or group is at least 10 participants (Nahartyo, 2012). Prior to this experiment research was conducted, firstly the experimental case material was discussed (pilot test) to ensure 
Table 1. Experimental Design $2 \times 2$ ANOVA

$\underline{\text { PsyCap }}$

\begin{tabular}{|l|l|c|c|}
\cline { 3 - 4 } \multicolumn{1}{c|}{} & High & Low \\
\cline { 2 - 4 } Adverse selection & Present & Group 1 & Group 2 \\
\cline { 2 - 4 } & $\begin{array}{l}\text { Not } \\
\text { Present }\end{array}$ & Group 3 & Group 4 \\
\hline
\end{tabular}

Table 2. Participant's Demography

\begin{tabular}{lccc}
\hline \multicolumn{1}{c}{ Info } & Detail & qty & $\%$ \\
\hline Gender & Male & 23 & 33.8 \\
& Female & 45 & 66.2 \\
Age & Total & 68 & 100.0 \\
& $21-25$ & 48 & 70.5 \\
& $26-30$ & 13 & 19.1 \\
\multirow{4}{*}{ Working Experience } & $31-35$ & 3 & 4.4 \\
& $>35$ & 4 & 5.8 \\
\multirow{4}{*}{ Length of work } & Total & 68 & 100.0 \\
& Working & 60 & 88.2 \\
& Not yet working & 8 & 11.8 \\
& Total & 68 & 100.0 \\
& $<1$ & 5 & 8.3 \\
& $1-4$ & 38 & 63.3 \\
& $5-9$ & 11 & 18.3 \\
& $10-15$ & 3 & 5.0 \\
& $>15$ & 3 & 5.0 \\
& Total & 60 & $100.0 \%$ \\
\hline
\end{tabular}

the validity of it and then the pilot test was also done. Based on that discussion and pilot test result, the researchers gained a lot of constructive feedback. Among these are the display of how material case is presented, the correction of ambiguous and confusing sentences, the order in which the PsyCap questionnaire was carried out took precendence than the case material, as well as the project case is illustrated using the adjusted currency value according to the current conditions. Furthermore, the the statistic resulft for the pilot test data also showed satisfactory results and in accordance with the predetermined predictions.

Total participant who takes part in this experiment is 86 participants. However, as much as 15 participants did not pass the manipulation check and three participants did not fill the experimental case completely, thus their respond can not be proceeded to next analysis stage. Table 2 show the detailed information about participant's demography. 
The experiment was done by using paper and pencil. All assignments for each treatment are allocated randomly. The process of randomizing the treatment assignment is carried out as follows.

First, the researcher looks for information about the total number of students who will be the candidate of the participants, after knowing the total participant of the researcher will directly print hardcopy of case material package as much as total estimation of the participants.

Every time researchers enter the classrom, researchers adjust the case material which will be distributed to the number of participants based on the appropriate composition.

To capture the value of PsyCap, it was taken from a questionnaire developed by Luthans and his colleagues (Luthans et al., 2007) which consisted of a total 24 five-scale likert questions. Although the questionnaire is a self-assessed method, in fact it is the most widely used in many studies on PsyCap as it is relatively easy to obtain the data (Newman, Ucbasaran, Zhu, and Hirst, 2014). For experimental case about escalation of commitment, this study adapted and modified some of the research instruments used by Harrel and Harrison (1994) and Chong and Suryawati (2010). Some modifications made to the case material are: the conversion of foreign currency dollars into rupiah, the context of the company name and type of company.

\section{Operational Definition, Variable Measurement}

The dependent variable in this study is the individual tendency to commit escalation of commitment. It is proxied in the form of individual decision preferences to continue or discontinue unprofitable projects, using a 10-point scale. The scale is divided at its midpoint (between 5 and 6). Options 1-5 indicate the decision to discontinue the project, which is closer to the number one indicates an increasingly certain indication for not continuing the project. While option 610 indicates the decision to continue the project, which is closer to the number ten indicates an increasingly certain indication to continue the project (Narsa and Supriyadi, 2019; Ang and Cheng, 2016). The first independent variable is an adverse selection condition with two levels present or not, which are detailed as follows:

a. Present: (1) Information about the poor performance of the project is known only to the project manager itself and will not be known to others either 
inside the company or outside the company; (2) The participants as managers are junior project managers.

b. Not present: (1) Information about the poor performance of the project is widely known to others either inside the company or outside the company; (2) Participants are senior project managers.

The second independent variable is Psychology Capital. PsyCap is a positive psychological state of an individual which consists of four variables (subscales). First, selfefficacy is an individu belief in terms of its ability to successfully pursue goals. Second, hope is the ability of individuals to find the path and means necessary to achieve a particular goal. Third, optimism is the individual realistic and flexible attribution of a positive event attributed to internal factors and negative events attributed to external factors. Fourth, resilience is the individual's ability to bounce back from negative events such as failure and uncertainty. Later responses from each subscale are summed and averaged to determine the composite score of the subscale. Then, the average value of each subscale will be added together and averaged to score the composite score for the PsyCap score of each participant. The overall average psycap score would be a benchmark to classify participants as high or low PsyCap. If the average psycap value of an individual falls below the average psycap value of all participants, it will classify as a low PsyCap group.

\section{Manipulation Check and Data Analysis Technique}

The question of manipulation given only about adverse selection conditions because it is only the variables that are manipulated in this study. The manipulation check question is given in the form of two statements and the participant is asked to select one of the statements that best describes the condition that the participant received in the case material. Participant must correctly answer both statements.

Prior to hypothesis testing, the data were analyzed by using descriptive statistics. Data analysis techniques to test the hypothesis used 
Table 3. Descriptive Statistic

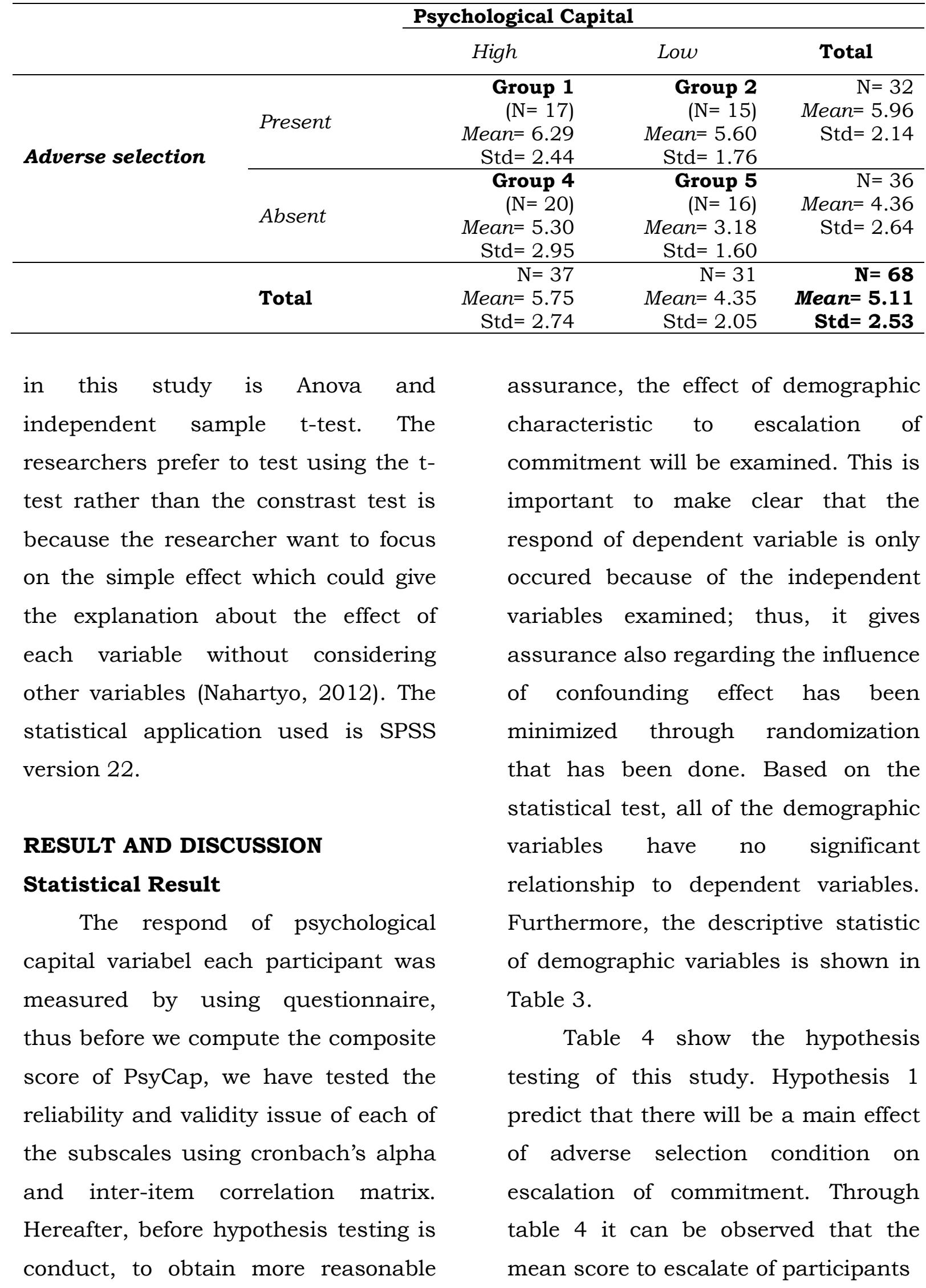


Table 4. Hypothesis Testing Results of Anova 2x2

\begin{tabular}{|c|c|c|c|c|}
\hline Source & $d f$ & Mean Square & $\mathbf{F}$ & Sig. \\
\hline Corrected Model & 3 & 29.097 & 5.417 & 0.002 \\
\hline Intercept & 1 & 1745.493 & 324.963 & 0.000 \\
\hline X1 (Adverse Selection) & 1 & 48.763 & 9.078 & $0.004 * * *$ \\
\hline X2 (PsyCap) & 1 & 33.098 & 6.162 & $0.016^{* *}$ \\
\hline $\mathrm{X} 1 * \mathrm{X} 2$ & 1 & 8.453 & 1.574 & 0.214 \\
\hline Error & 64 & 5.371 & & \\
\hline Total & 68 & & & \\
\hline Corrected Total & 67 & & & \\
\hline
\end{tabular}

which are in adverse selection condition (5.96) is higher than those who do not in adverse selection condition (4.36). Based on $2 \times 2$ anova test, the two mean score show a significant difference $(\mathrm{F}=9.078$; $\mathrm{p}<0.01$ ) thus hypothesis 1 is supported.

Next, related to hypothesis 2 , as explained in research method section, no manipulation was done for PsyCap. The level of participant's PsyCap was captured by providing a PsyCap questionnaire that participant must fill out compeletely. To classify participant into a group of high PsyCap or low PsyCap, was done by firstly calculate the average score of yCap among all of the participants, which is 3.972. Then, the average score of PsyCap for each participant compared with that score. If participant's average score below that score, participant will be grouped as low PsyCap (group 2 or 5 depend also with the condition of adverse selection received) and vice versa for high PsyCap group.
Hypothesis 2 predict that there will be main effect also for PsyCap on escalation of commitment. The average score of participants who have high PsyCap is 5.75, and then for participants who have low PsyCap is 4.35. Statistical results indicate that those two numbers are different significantly $(F=6.162 ; p<0.05)$, thus hypothesis 2 is supported. Lastly, for hypothesis 3 which predict that there will be an interaction effect between adverse selection and Psycap, the statistical result shows insignificant effect $\quad(F=1.574 ; \quad p>0.20)$, thus hypothesis 3 is not supported. The interaction plot can be seen in Picture 1.

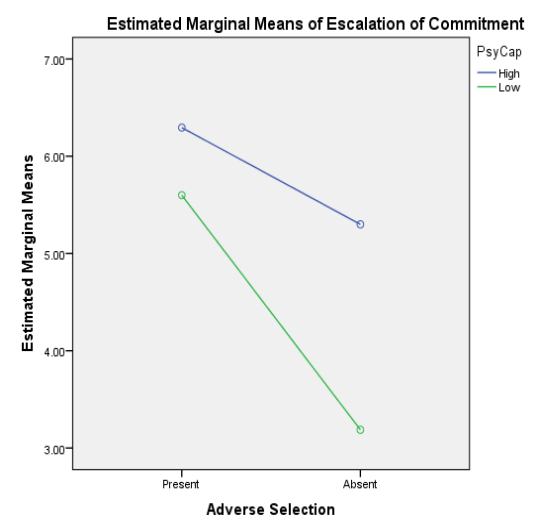

Picture 1. The Interaction Plot 


\section{Discussion}

This study found that adverse selection condition resulting in greater tendency to escalate commitment among master student who become the surrogate of project managers. The agency problem manipulated in this study occurs because of two concepts, namely information asymmetry and incentive to shrik. Those two concepts are also the basic concepts to understanding the agency theory. The condition of information asymmetry occurs when the manager has more information than the principal so that the principal is not fully aware of the current position of the project. The incentive to shirk condition occurs when the reward that the manager receives to continue the project is greater than the reward that will be accepted if the project stops. These two conditions place managers to reach decisions that reflect the manager's personal interests that are contrary to the interests and goals of the company. As a result, it is become a rational thing for the managers to continue unprofitable projects, eventhough it is wrong from the viewpoint of the company.

In fact, many consistent findings have been also found by previous researchers regarding the effect of adverse selection to escalation of commitment, such as Harrison dan Harrell (1993), Harrell dan Harrison (1994), Berg et al (2009) and Booth dan Schulz (2004). But to keep an eye on the effects of adverse selection remains important since an agency relationship will always exist on the company and either the concept of asymmetry information or incentive to shrink could be modified by the company (Berg et al., 2009).

Prior researchs suggested that the individual variable of decisionmaker is constantly substantial to be understood because capability of how decision-maker will also determine the result of decision-making procees, especially in escalation of commitment (Korzaan and Morris, 2009; Chong and Syarifuddin, 2009). By understanding the decisionmaker's individual variable, allows the company to be able to design information systems to achieve more useful results or decision (Gul, 1984). Thus, this study also tests the effect of psychological factor, namely PsyCap which is a relatively emerging variables in Positive Psychological literature. PsyCap is defined as a positive psychological state of an individual characterized by four individual variables which is selfefficacy, hope, optimism, and resilience and difficulties, it will 
persist and will bounce back or even stronger to achieve success-resilience.

The result of this study, regarding the main effect of psychological capital, is similar with what have been found by previous researchers who try to examine the relationship between each of PsyCap's component to escalation of commitment. Individuals who have a high PsyCap (could also be said who have a relatively high self-efficacy, hope, optimism, and resilience) tend to continue their decision beyond the limitation of rational decision making because they believe that they able to successfully manage the unprofitable project despite many obstacles confronted them. When project managers are faced with negative feedback, which is the project that they handled suffering a big loss, along with high hope, they tend to have a positive anticipation expectation. They constantly tried to find a new way or strategy to reverse unfavorable results into favorable one (Liang and Dunn, 2010). Along with high optimism, they also tend to believe that the obstacles or failures they suffering now are only impermanent, thus they will work harder. Eventhough they still facing a new negative feedback again in the future, they are able to survive and quickly recovered from the downturncorrespond for high resilience.

Furthermore, Sleesman et al. (2012) argue that the agency relationship is the most used concept when talking about structural determinant in escalation of commitment. However, to test structural determinant together with psychological determinant in one study will be interesting because as Saks and Ashforth (2000) state that understanding the whole mechanism of how a decision-maker react in different situation is by considering not only structural factor but also psychological factor. Thus, it is also important to figure out the meaning of interaction effect result between adverse selection and psychological capital.

This study predicts that under adverse selection condition, the project manager with high PsyCap tend to more escalate their decision than the project manager with low PsyCap. That is because project managers with high PsyCap are increasingly motivating in completing tasks and ignoring any obstacles especially when experiencing adverse selection conditions which allow them to more willing to take risks to maintain their reputation and also to gain the rewards. 
However according to statistical result, there is no interaction effect of adverse selection and PsyCap. We presume that this is because individuals who have high PsyCap are people who tend to behave honestly. Thus, when faced with an unfair condition - that the information about the negative feedback of project is only available to them (not symmetrical) and preceding selfinterest that the company furthermore, make individuals with high PsyCap will avoid act opportunistic.

According to organizational justice theory, the justice perception of an individual will affect their organizational commitment and the manner when they working (Koh and Boo, 2004). If project managers think that their company is being ethical, they tend to feel that their company being far to them, thus even confronted with ethical dilemma, they will act less opportunistic. As found by Sehhat et al. (2015), hoe PsyCap of each individual formed is highly dependent of ethical aspect in itself. Their study contributes in giving shed light regarding the mechanisms underlying how ethics is able to enhance self-efficacy, hope, optimism, and resilience of individual. Thus, this may be the justification of unsopported hypothesis in this study.

\section{CONCLUSION, IMPLICATION \& LIMITATION}

The objective of this study was to examine the effect of PsyCap, adverse selection condition, and the effect of PsyCap condition along with adverse selection condition on manager's tendency to escalate their commitment. From a theoretical point of view, the exploration of the influence of PsyCap, as a new emerging variable, on decision making involving escalation situations, this research enriches empirical evidence on the escalation literature of commitments especially with regard to psychological determinants. This research also enriches empirical evidence to the PsyCap literature history, since PsyCap always identified with the desired outcome at work when it may not always be that way. Furthermore, from a practical point of view, this study is expected to provide an overview of the importance of identifying individual variables on organizational decision-making.

Gul (1984) stated that by understanding decision-maker's individual variables, allows the company to design control mechanism - such as information systems - in order to gain more effective decision-making procees. However, the result of this study suggest that it would be very 
challenging for the company to design control mechanisms (situational factors) which try to relate it with the individual factors. Both of them are very specifically differ in nature. It would be very difficult to cope a problem with a solution that not came from the same origin (one talking about the external and multi factor - agency relationship, one talking about internal and single factor individual variable which is PsyCap). Moreover, situational factors are very broad. As presumed in this study, ethical factors could be another explanation of insignificant result of interaction effect.

Some of limitations of this study should be considered. The use of experimental method results in low external validity. The case material used in this study is a simplified form of the real case in the working environmental, thus it might be needing a high caution to generalize the finding. Furthermore, eventhough this study using laboratory experiment, but one of independent variables used in this study, which is PsyCap, was not manipulate and only capture it by providing the questionnaire. The future research can try to find an appropriate way in manipulating the level of PsyCap due to its nature that it open to be formed, perhaps by giving a short motivation video, etc. Future study could also consider other omitted variable in which might affect the escalation of commitment especially in adverse selection condition, like the ethical factors such as moral philosophy, company's code of ethics, sanction, reward. Lastly this study only tests the determinant variables, the future study could try to combine it with de-escalation strategy which suit for individual with high PsyCap.

\section{REFERENCES}

Ang, N., \& Cheng, M. M. (2016). Does Self-Certification Encourage or Reduce Opportunistic Behavior? Behavioral Research in Accounting, 28(2), 1-16. https://doi.org/10.2308/bria51468

Avey, J. B., Reichard, R. J., Luthans, F., \& Mhatre, K. H. (2011). MetaAnalysis of the Impact of Positive Psychological Capital on Employee Attitudes , Behaviors, and Performance. 22(2). https://doi.org/10.1002/hrdq

Babatunde, A. Y. (2016). Perceived Self-Efficacy and Dispositional Optimism in Leaders' Behavioral Escalation of Commitment [Walden University]. https://scholarworks.waldenu.ed $\mathrm{u} /$ dissertations/2200

Bandura, A. (1997). Self-efficacy: The Exercise of Control. Freeman.

Bazerman, M. H., Giuliano, T., \& Appelman, A. (1984). Escalation of Commitment in Individual and 
Group Decision Making. Organizational Behavior and Human Performance, 33(2), 141152 .

Berg, J. E., Dickhaut, J. W., \& Kanodia, C. (2009). The Role of Information Asymmetry in Escalation Phenomena: Empirical Evidence. Journal of Economic Behavior and Organization, 69(2), 135-147. https://doi.org/10.1016/j.jebo.2 007.07.007

Booth, P., \& Schulz, A. K.-D. (2004). The Impact of an Ethical Environment on Managers' Project Evaluation Judgments Under Agency Problem Conditions. Accounting, Organizations and Society, 29156), 473-488. https: / / doi.org/10.1016/S03613682(03)00012-6

Bowen, M. G. (1987). The Escalation Phenomenon Reconsidered: Decision Delemmas or Decision Errors? The Academy of Management Review, 12(1), 5266.

Bragger, J. D., Bragger, D., Hantula, D. A., Kirnan, J., \& Kutcher, E. (2003). When Success Breeds Failure: History, Hysteresis, and Delayed Exit Decisions. Journal of Applied Psychology, 88, 6-14.

Brockner, J. (1992). The Escalation of Commitment to a Course of Action: The Escalation of Commitment to a Failing Course of Action: Toward Theoretical Progress. Academy of Management Review, 17(1), 3961.

https: / /doi.org/10.5465/AMR.19 81.4285694

Buxton, M., \& Rivers, R. (2014). Escalation of Commitment: The Effects of Magnitude of Loss,
Monitoring and the Presence of an Alternative Investment. Can a Project 90\% Complete be Stopped? Journal of Accounting and Finance, 14(5), 152.

Chong, V. K., \& Suryawati, R. F. (2010). De-escalation Strategy: The Impact of Monitoring Control on Managers' Project Evaluation Decisions. Journal of Applied Management Accounting Research, 8(2), 39-50.

Chong, V. K., \& Syarifuddin, I. (2010). Escalation of Commitment to Unprofitable Projects: An Experimental Investigation of the Effect of Conformity Pressure and Self-esteem. Accounting, Accountability \& Performance, $16(1 \& 2), 1-24$.

Csikszentmihalyi, M. (1997). Finding Flow: The Psychology of Engagement With Everyday Life (1st ed.). Basic Books.

Dewi, H. R., \& Supriyadi. (2012). The Effectiveness of Monitoring Controls and Individual Moral Reasoning in the De-escalation of Commitments. The Indonesian Journal of Accounting Research, 15(1), 1-20.

Harrell, A., \& Harrison, P. (1994). An Incentive to Shirk, Privately Held Information, and Managers' Project Evaluation Decions. Accounting, Organizations and Society, 19(7), 569-577.

Harrison, P. D., \& Harrell, A. (1993). Impact of "Adverse Selection" on Managers' Project Evaluation Decisions. Academy of Management Journal, 36(3), 635643.

https://doi.org/10.2307/256596

Kanodia, C., Bushman, R., \& Dickhaut, J. (1989). Escalation Errors and the Sunk Cost Effect: 
An Explanation Based on Reputation and Information Asymmetries. Journal of Accounting Research, 27(1), 5977. https: / / doi.org/10.2307/249120 7

Kisfalvi, V. (2000). The Threat of Failure, The Perils of Success and CEO Character: Sources of Strategic Persistence. Organizational Studies, 21(3), 611-639. https: / / doi.org/10.1177/017084 0600213006

Kluemper, D. H., Little, L. M., \& DeGroot, T. (2009). State or Trait: Effects of State Optimism on Jobrelated Outcomes. Journal of Organizational Behavior, 30(2), 209-231.

https://doi.org/10.1002/job.591

Leigh, B. C. (1999). Peril, Chance, and Adventure: Concepts of Risk, Alcohol Use and Risky Behavior in Young Adults. Addiction, 94, 371-383.

Luthans, F. (2002a). Positive organizational behavior: Developing and managing psychological strengths. Academy of Management Executive, 16(1), 57-72.

https: / / doi.org/10.5465/AME.20 02.6640181

Luthans, F. (2002b). The Need For and Meaning of Positive Organizational Behavior. Journal of Organizational Behavior, 23, 695-706.

Luthans, F., Youssef, C. M., \& Avolio, B. J. (2007). Psychological Capital: Developing the Human. Oxford University Press.

Mahlendorf, M. D., \& Wallenburg, C. M. (2013). Public Justification and Investment in Failing
Projects: The Moderating Effect of Optimistic Outcome Expectations. Journal of Applied Social Psychology, 43(11), 22712286.

https://doi.org/10.1111/jasp. 12 177 Majer

Moser, K., Wolff, H.-G., \& Kraft, A. (2013). The De-escalation of Commitment: Predecisional Accountability and Cognitive Processes. Journal of Applied Social Psychology, 43(2), 363376.

https://doi.org/10.1111/j.15591816.2012.01005.x

Narsa, N. P. D. R. H., \& Narsa, I. M. (2018). The Relationship Between Psychological Capital and the Escalation of Commitment in Capital Project Continuation Decisions: Empirical Evidence from Indonesia. International Journal of Economics and Management, 12(Special Issue 1), 91-104.

Narsa, N. P. D. R. H., \& Supriyadi. (2019). The role of companies' codes of ethics in mitigating managers' escalation behavior in the frame of agency theory. AsiaPacific Journal of Accounting and Economics, 26(1-2), 131-149. https://doi.org/10.1080/160816 25.2019 .1546563

Narsa, N. P. D. R. H., \& Wijayanti, D. M. (2021). The Importance of Psychological Capital on the Linkages between Religious Orientation and Job Stress. Journal of Asia Business Studies, Vol. ahead(No. ahead-of-print). https://doi.org/https://doi.org/ 1 0.1108/JABS-09-2018-0251

Newman, A., Ucbasaran, D., Zhu, F., \& Hirst, G. (2014). Psychological Capital: A Review and Synthesis. Journal of Organizational Behaviorq, 35, S120-S138. 
https://doi.org/10.1002/job.191 6

Roberts, R. P. (2013). The Impact of Authentic Leadership and Adverse Selection Conditions on Escalation of Commitment Committee Members. Drexel University.

Ronay, R., Oostrom, J. K., Lehmannwillenbrock, N., \& Vugt, M. Van. (2017). Pride Before The Fall: (Over)confidence Predicts Escalation of Public Commitment. Journal of Experimental Social Psychology, 69, 13-22.

Ross, J., \& Staw, B. M. (1993). Organizational Escalation and Exit: Lessons From the Shoreham Nuclear Power Plant. Academy of Management Journal, 36(4), 701732 .

Rutledge, R. W., \& Karim, K. E. (1999). The Influence of SelfInterest and Ethical Considerations on Managers' Evaluation Judgments. Accounting, Organizations and Society, 24(2), 173-184.

Saks, A. M., \& Ashforth, B. E. (2000). Change in Job Search Behaviors and Employment Outcomes. Journal of Vocational Behavior, 56, 277-287.

Salter, S. B., \& Sharp, D. J. (2001). Agency Effects and Escalation of Commitment: Do Small National Culture Differences Matter? The International Journal of Accounting, 36(1), 33-45.

Schulz-Hardt, S., Thurow-Kröning, B., \& Frey, D. (2009). Preferencebased Escalation: A New Interpretation for The Responsibility Effect in Escalating Commitment and Entrapment. Organizational Behavior and Human Decision Processes, 108(2), 175-186. https://doi.org/10.1016/j.obhdp. 2008.11.001

Sleesman, D. J., Conlon, D. E., McNamara, G., \& Miles, J. E. (2012). Cleaning Up the Big Muddy: A Meta-Analytic Review of the Determinants of Escalation of Commitment. Academy of Management Journal, 55(3), 541562.

Snyder, C. R. (2000). Handbook of Hope: Theory, Measures, and Applications. Academic Press.

Taylor, S. E., \& Stanton, A. L. (2007). Coping Resources, Coping Processes, and Mental Health. Annual Review of Clinical Psychology, 3(1), 377-401.

Venkatesh, R., \& Blaskovich, J. (2012). The Mediating Effect of Psychological Capital on the Budget Participation-Job Performance Relationship. Journal of Management Accounting Research, 24(1), 159175.

https:/ / doi.org/ 10.2308/jmar50202

Whyte, G., Saks, A. M., \& Hook, S. (1997). When success breeds failure: The role of self-efficacy in escalating commitment to a losing course of action. 18(April 1996), 415-432.

Xing, C., Sun, J., \& Resources, H. (2013). The role of Psychological Resilience and Positive Affect in Risky Decision-Making. 48(5), 935-943.

Youssef, C. M., \& Luthans, F. (2007). Positive Organizational Behavior in the Workplace: The Impact of Hope, Optimism, and Resilience. Journal of Management, 33(5), 774-800.

https://doi.org/10.1177/014920 6307305562 